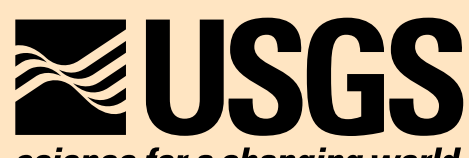

science for a changing world

Studies by the U.S. Geological Survey in Alaska, 2007

\title{
Channel Incision and Water-Table Decline Along a Recently Formed Proglacial Stream, Mendenhall Valley, Southeastern Alaska
}

Professional Paper 1760-E

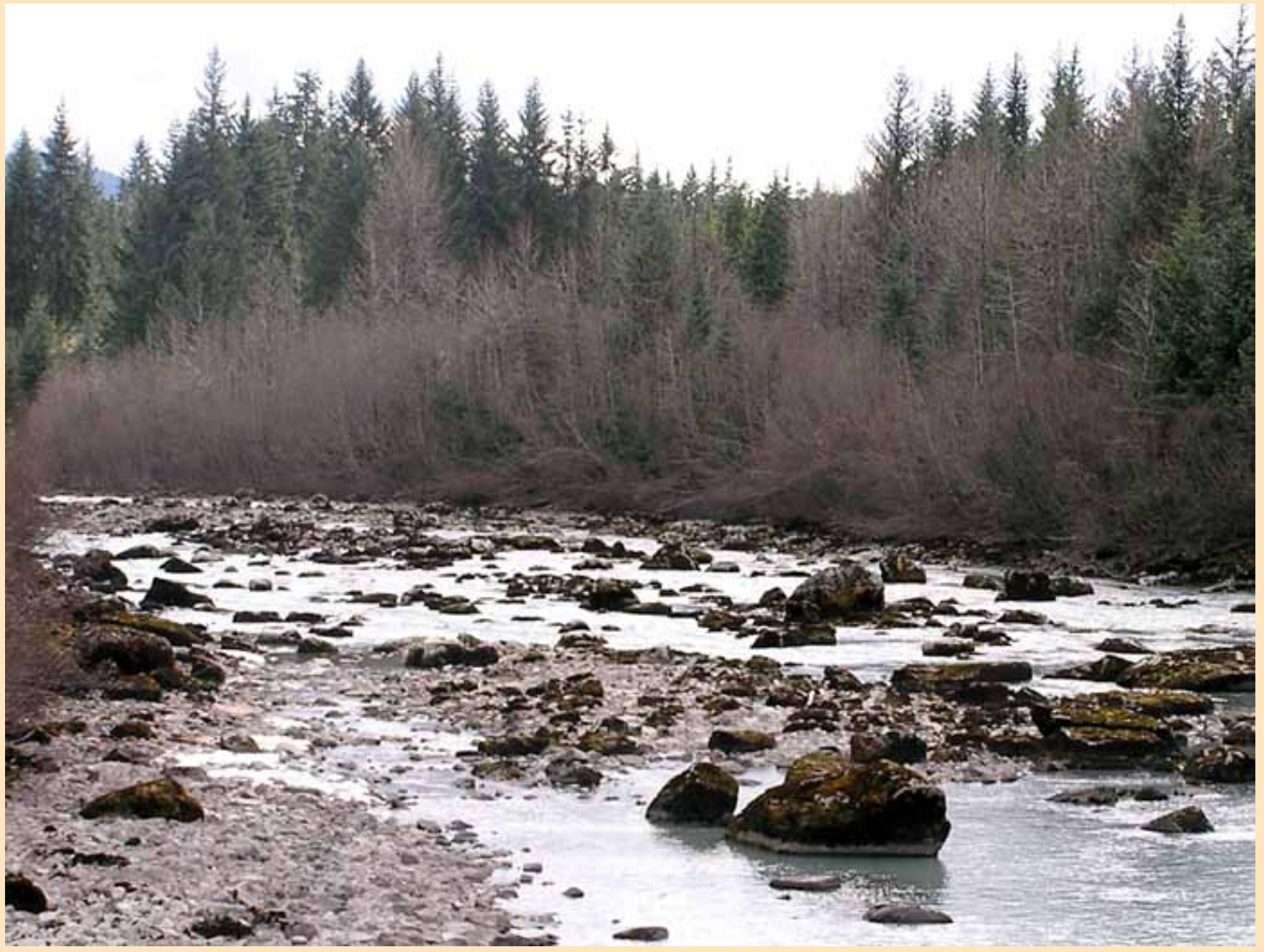

U.S. Department of the Interior U.S. Geological Survey 
This page intentionally left blank 
Studies by the U.S. Geological Survey in Alaska, 2007

\section{Channel Incision and Water-Table Decline Along a Recently Formed Proglacial Stream, Mendenhall Valley, Southeastern Alaska}

By Edward G. Neal

Professional Paper 1760-E 


\section{U.S. Department of the Interior KEN SALAZAR, Secretary}

\section{U.S. Geological Survey Suzette M. Kimball, Acting Director}

U.S. Geological Survey, Reston, Virginia: 2009

This report and any updates to it are available online at: http://pubs.usgs.gov/pp/1760/e/

For more information about the USGS and its products:

Telephone: 1-888-ASK-USGS (1-888-275-8747)

World Wide Web: http://www.usgs.gov/

Any use of trade, product, or firm names in this publication is for descriptive purposes only and does not imply endorsement by the U.S. Government.

Although this report is in the public domain, it may contain copyrighted materials that are noted in the text. Permission to reproduce those items must be secured from the individual copyright owners.

Produced in the Western Region, Menlo Park, California

Manuscript approved for publication, August 9, 2009

Text edited by Tracey Suzuki

Layout and design by Stephen L. Scott

Suggested citation:

Neal, Edward G., 2009, Channel incision and water-table decline along a recently formed proglacial stream, Mendenhall Valley, southeastern Alaska, in Haeussler, P.J., and Galloway, J.P., Studies by the U.S. Geological Survey in Alaska, 2007: U.S. Geological Survey Professional Paper 1760-E, 15 p.

FRONT COVER

Photo of erosion resistant reach of the Mendenhall River, southeastern Alaska. 


\section{Contents}

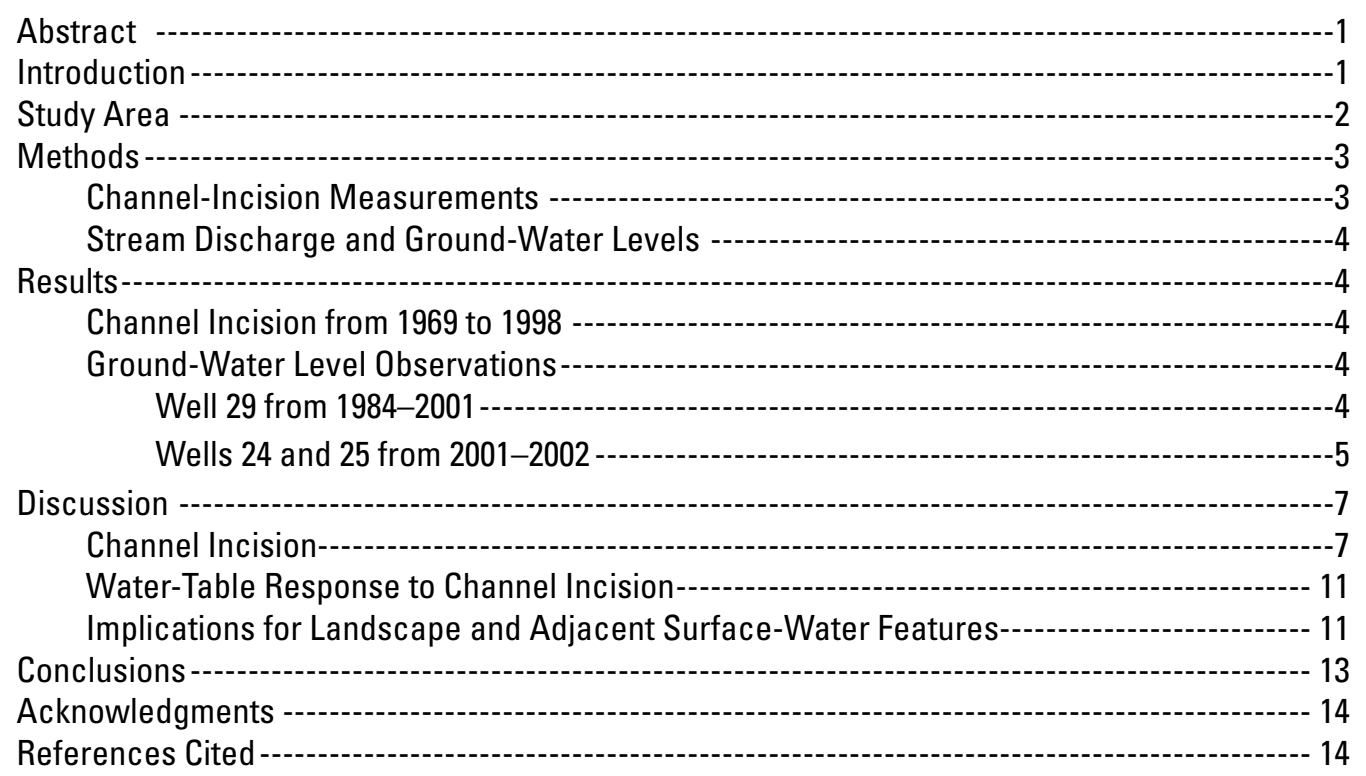

\section{Figures}

1. Location map of the Mendenhall Valley, southeastern Alaska-----------------------------2

2. Historical photo of the Mendenhall Valley---:-

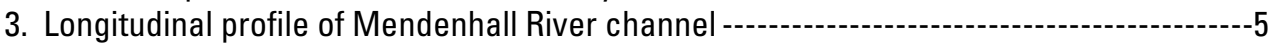

4. Monthly mean water levels recorded in observation well 29 --

5. Plot showing changes in groundwater levels in observation wells 24 and 25 -----------6

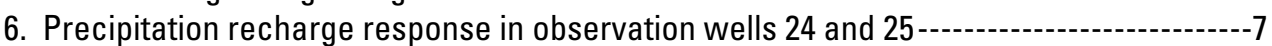

7. Water levels in observation wells 24 and 25---8

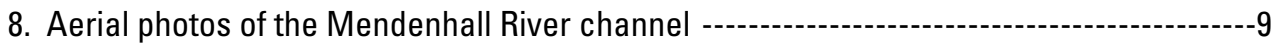

9. Photo of erosion resistant reach of the Mendenhall River showing the channel

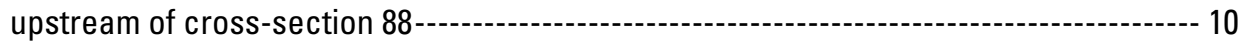

10. Photo of Mendenhall River showing a reach downstream of cross-section 74 ---------- 10

11. Cross sections showing inferred evolution of the Mendenhall River channel------------- 12

12. Aerial photos taken in 1948 and 2005 showing forest encroachment into the wetlands - 13

\section{Tables}

1. Changes in minimum and mean bed elevations from 1969 to 1998 for seven cross sections surveyed on the Mendenhall River 
This page intentionally left blank 


\title{
Channel Incision and Water-Table Decline Along a Recently Formed Proglacial Stream, Mendenhall Valley, Southeastern Alaska
}

\author{
By Edward G. Neal
}

\section{Abstract}

Retreat of the Mendenhall Glacier, in southeastern Alaska, resulted in the formation of Mendenhall Lake, which has reduced the supply of coarse sediment to the proglacial Mendenhall River. Channel geometry surveys conducted in 1969 and 1998 over a $5.3 \mathrm{~km}$ reach of the Mendenhall River revealed reductions in mean bed elevations ranging from 0.4 to 1.5 meters based on cross sections replicated at 7 locations. Channel incision in the Mendenhall River is believed to be the result of a combination of factors resulting from localized and region-wide glacial retreat.

In addition to a reduction of river stage due to channel incision, a decline in water-table elevations of about $0.6 \mathrm{~m}$ during a 17-year period from 1984 to 2001 was identified in an observation well located $250 \mathrm{~m}$ from the incising stream channel. Water-table elevations $600 \mathrm{~m}$ from the incising channel in the adjacent alluvial outwash aquifer respond in phase to changes in river stage, indicating water-levels in the adjacent aquifer are declining in response to river-channel incision. This study suggests channel incision can rapidly lower watertable elevations for large distances in the adjacent aquifer, potentially modifying the hydrology to a degree capable of influencing adjacent surface-water features, such as off-channel wetlands and flood-plain side channels.

\section{Introduction}

Formation of proglacial lakes in the headwaters of river drainages has been shown to induce downstream progressing channel incision, which is initiated when bedload and coarse grained suspended sediment is trapped in the newly formed lake. Water emerging from the lake has little or no sediment load yet possesses excess energy required to transport sediment. Kondolf (1997) refers to this type of sediment deficient flow, induced by gravel extraction, as "hungry water" prone to erode the channel bed and banks resulting in channel incision. Galay (1983) and Chew and Ashmore (2001) provide modern day examples of channel incision induced by glacial retreat and the formation of lakes near the terminus of these glaciers. These authors concluded that deprivation of sediment supply due to lake formation resulted in the formerly braided channels adoption of an incising single-thread pattern. Channels downstream of newly constructed dams have exhibited similar channel transitions (Galay, 1983; Williams and Wolman, 1984; Kondolf and Swanson, 1993) as the flows emerging from the base of the dams also can be deficient in sediment.

Many problems can be directly attributed to channel incision, such as the undermining of bridges and other engineered structures, loss of land (Kondolf and Swanson, 1993), and reduced diversity of fish habitat (Shields and others, 1994). Additional indirect impacts of channel incision also have been identified. Loss of riparian vegetation adjacent to incising stream channels has been documented on the Mojave River in California (Scott and others, 2000) and in the flood plain of an agricultural watershed in the midwestern United States (Schilling and others, 2004). Incising channels also have been linked to the disappearance of off-channel wetlands in Great Sand Dunes National Monument, Colorado (Wurster and others, 2003) and the dewatering of remnant side channels of the Rhone River, France (Bornette and Heiler, 1994).

The indirect impacts of channel incision on aquatic landscape features have been linked to a concomitant reduction in water-table elevations of the adjacent alluvial or flood-plain aquifers. Although it is recognized that incision induces adjacent aquifers to drain to a lower elevation (Galay, 1983; Kondolf, 1997), the spatial extent and magnitude of aquifer-level response to channel incision is rarely documented and likely to be highly variable when considering the wide range of transmissivity found in these aquifers. Furthermore, processes like channel incision and associated reductions in aquifer elevation can be difficult to detect in the absence of long-term monitoring of required parameters.

The proglacial Mendenhall River flows through Mendenhall Valley in Southeastern Alaska. Glacial recession on a local (and perhaps regional) scale coupled with the recent formation of both Mendenhall River and Mendenhall Lake has provided an opportunity to examine the interactions between an incising stream channel and the adjacent outwash aquifer. Due, in part, to the extended chronological nature of the development of 
these processes, the data analyzed in this investigation was drawn from an array of data collected since 1893. The objectives of this study were to (1) document and briefly examine channel incision and controls since the formation of proglacial Mendenhall Lake, (2) document the influence of channel incision on the groundwater levels in the adjacent aquifer that extends across a broad, low-relief outwash plain, and (3) provide a conceptual model of the response of the aquifer to incision-induced reductions in river stage.

\section{Study Area}

The Mendenhall River is the largest stream within Mendenhall Valley, and it currently flows along the western margin of the study area (fig. 1). Elevations in Mendenhall River Basin, an area of about $267 \mathrm{~km}^{2}$, range from sea level to 2,100 $\mathrm{m}$. The Mendenhall River exhibits large, seasonal variations in discharge as it is sourced principally from meltwater of the Mendenhall Glacier, which covers nearly two-thirds of the

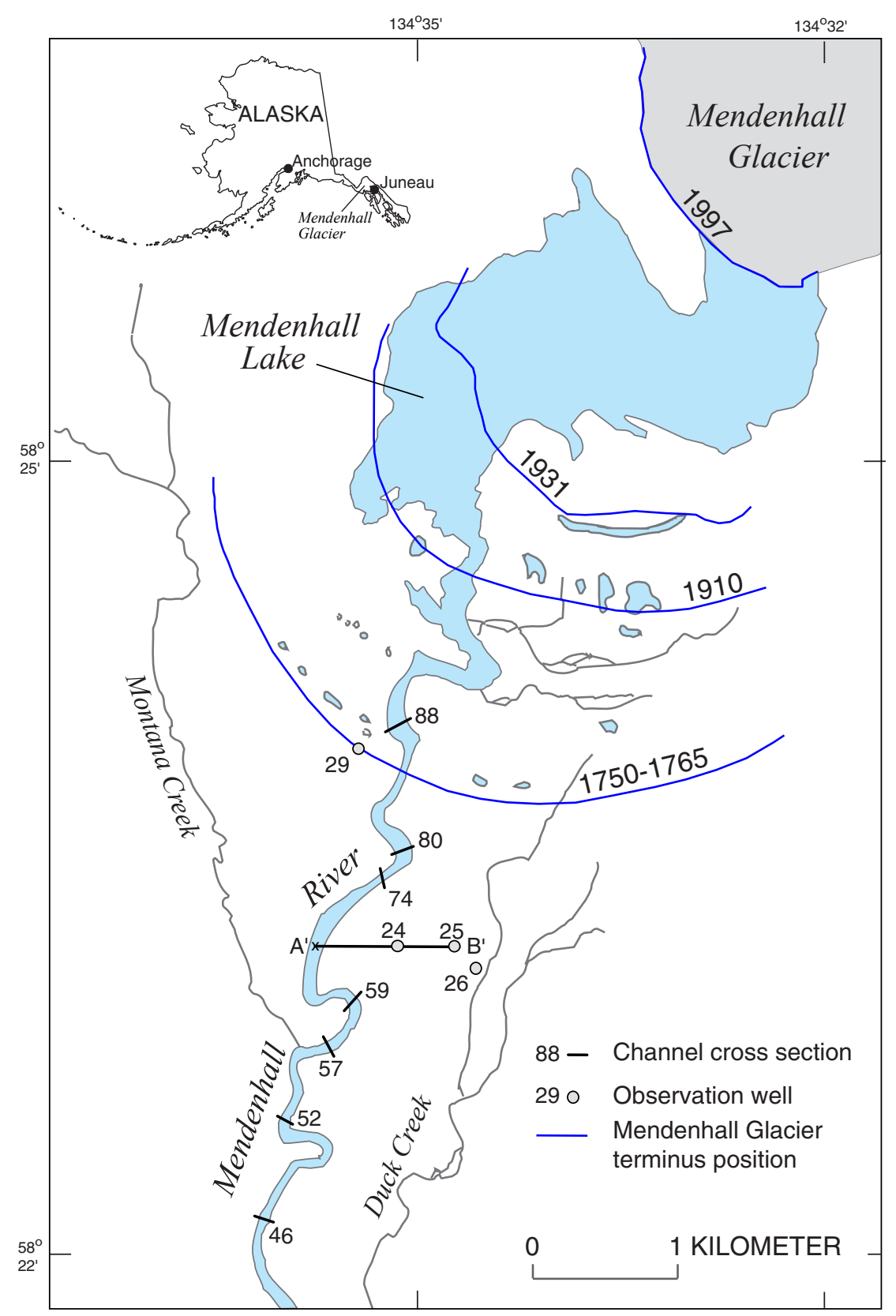

Figure 1. Location map of the Mendenhall Valley, southeastern Alaska. The locations of water-table profile transects, replicated cross-section surveys, and several historical glacial-terminus positions also are shown. 
basin. Discharge is influenced largely by temperature, and peak flows typically are during late summer when runoff from heavy precipitation combines with enhanced glacial melting due to warm temperatures. From 1965 through 2005, average annual mean discharge was $33.5 \mathrm{~m}^{3} / \mathrm{s}$ and ranged from a minimum monthly mean of $2.6 \mathrm{~m}^{3} / \mathrm{s}$ in February to a maximum monthly mean of $95.4 \mathrm{~m}^{3} / \mathrm{s}$ in August (Jackson and others, 2006).

The Mendenhall Glacier probably began its most recent recession in about 1770 (fig. 1; Miller 1975). Sometime prior to 1893 , the glacier's terminal moraine was breached at the current outlet of Mendenhall Lake, and the Mendenhall River carved a channel through outwash deposits near its present location. Before this, meltwater from the glacier flowed over moraine material into a broad, braided channel on the eastern side of the valley (fig. 2). Since 1909 the glacier has thinned as much as $200 \mathrm{~m}$ at lower elevations, and the terminus has retreated $3 \mathrm{~km}$, resulting in the formation of Mendenhall Lake around 1931 (Motyka and others, 2002), which reduced the supply of coarse sediment to the Mendenhall River. Current sources of coarse sediment for the Mendenhall River are derived primarily from channel and bank erosion. Montana Creek (fig. 1) also contributes coarse material to the lower reaches of the river. Much of the west bank of the Mendenhall River remains undeveloped and forested in contrast with the east bank, which has undergone extensive development since the early 1960s. Development has included several bank-hard- ening projects, which have likely constrained lateral channel migration.

Downstream from the lake, the Mendenhall River flows along the western side of the U-shaped Mendenhall Valley, which was formed by glaciation during the Pleistocene Epoch. The ice sheet in the valley was 1,200-1,500 m thick at its maximum and began to recede about 17,000 years ago (Coulter and others, 1965). As the ice sheet retreated, glaciomarine sediments were deposited and are overlain by younger outwash deposits of variable thickness. Depths of these deposits approach $200 \mathrm{~m}$ near the mouth of the valley. The older outwash deposits are covered by low-relief Holocene outwash deposits that blanket the majority of the valley to a depth of about $18 \mathrm{~m}$ (Miller, 1975). These outwash deposits make up the shallow unconfined aquifer of the Mendenhall Valley.

\section{Methods}

\section{Channel-Incision Measurements}

The U.S. Army Corps of Engineers Hydrologic Engineering Center River Analysis System modeling package was used in conjunction with Mendenhall River channel-survey data to measure changes in both mean and minimum channel-bed elevation. This model incorporates cross-sectional surveys of channel geometry, reach lengths, and discharge data to pro-

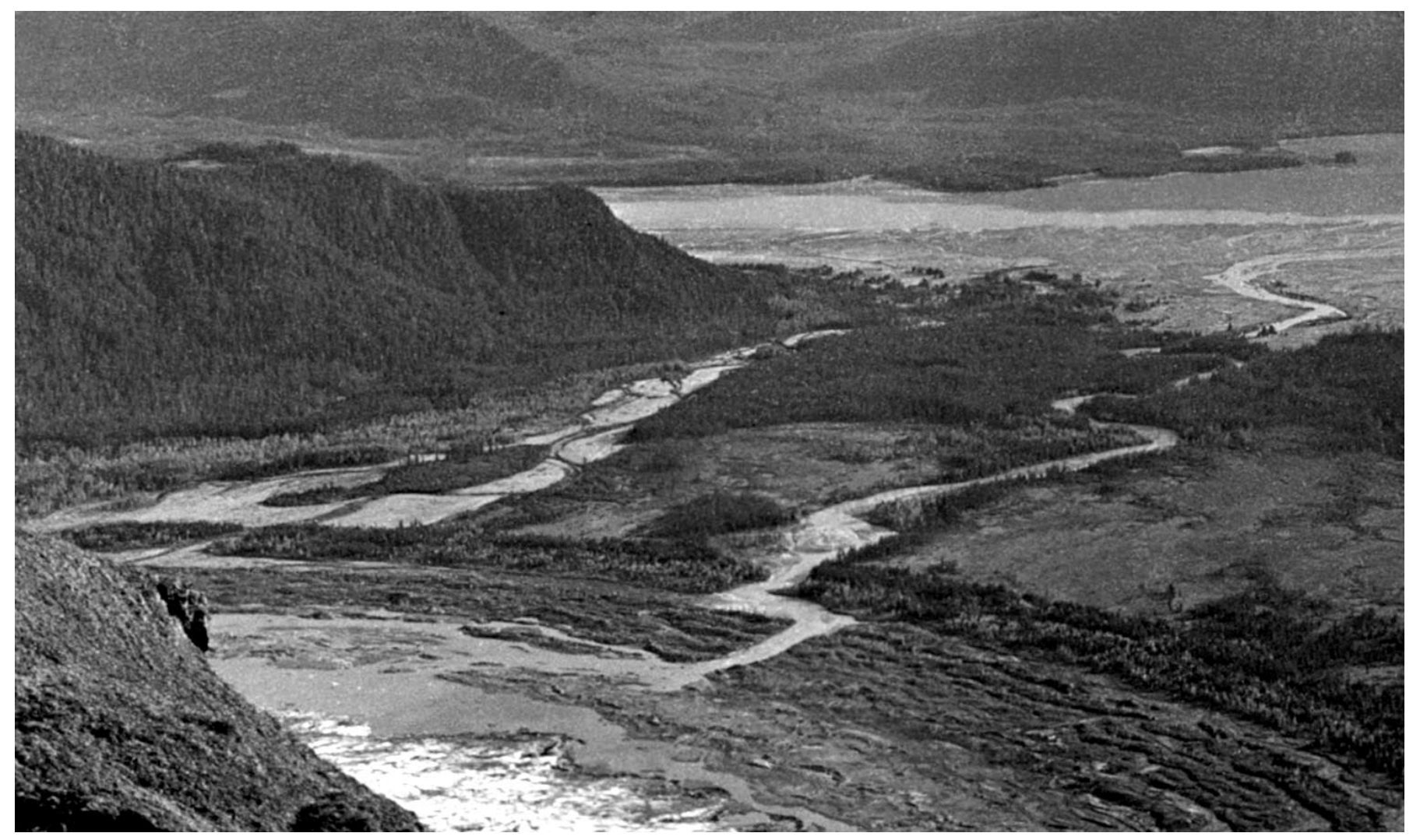

Figure 2. Historical photo of the Mendenhall Valley, southeastern Alaska, showing the Mendenhall River emerging from the Mendenhall Glacier and abandoned outwash channels on the eastern side of the Valley. (Photo by W. Ogilvie, 1893.) 
duce water-surface profiles for selected discharges. To measure changes in minimum bed elevation, cross-sectional surveys of channel geometry were extracted from a model developed from survey data collected in 1969 (Federal Emergency Management Agency, 1990) and compared to similar surveys conducted by the United States Geological Survey (USGS) in 1998 (Neal and Host, 1999). The change in minimum bed elevation was calculated as the difference in minimum bed elevations between the two surveys.

The locations of seven cross sections surveyed in 1998 replicated cross-section locations surveyed in 1969 (fig. 1). The change in mean bed elevation at each of these seven replicated cross-sectional surveys was calculated by routing the mean annual discharge of the Mendenhall River through both the 1969 and 1998 surface-water profile models. The average depth at each of the seven replicated cross sections was subtracted from the modeled water-surface elevation to derive the mean bed elevations as described by Jacobson (1995).

\section{Stream Discharge and Groundwater Levels}

The USGS has recorded Mendenhall River stage and discharge at the outlet of Mendehall Lake since 1965. The water-surface profile model developed by Neal and Host (1999) was used to verify that stage changes recorded at the lake outlet were representative of stage changes in the downstream reaches of the river. This allowed stage changes throughout the lower reaches of the river to be related to changes in water levels in the adjacent aquifer.

A longitudinal transect of streamflow-discharge measurements conducted by the USGS on March 5, 1984 (Bigelow and others 1985), showed a measurable gain in discharge of 1.0 $\mathrm{m}^{3} / \mathrm{s}$ from the aquifer in the reach between cross sections 88 and 46 (fig. 1). Measurements were taken during a period of stable flow conditions, and Mendenhall River discharge at Mendenhall Lake outlet was $2.3 \mathrm{~m}^{3} / \mathrm{s}$. No attempt has been made to measure the exchange of water between the aquifer and river during high flows due to the difficulties involved in accurate measurement of this exchange.

Observation well 29 is $250 \mathrm{~m}$ west of the Mendenhall River channel along the base of a large terminal moraine (fig. 1). Penetrating sand and gravel deposits, well 29 is constructed of $15-\mathrm{cm}$ diameter PVC casing screened from 9.2 to $12.2 \mathrm{~m}$. The USGS recorded continuous groundwater levels in well 29 from October 1984 through September 2001.

Observation wells 24, 25, and 26 (fig. 1) are 13.5, 15, and $16 \mathrm{~m}$ deep, respectively, and penetrate outwash deposits of sand and gravel. Water levels in observation wells were measured with submersible pressure transducers and recorded hourly from April 2001 through September 2002. Water-level recordings were calibrated with intermittent measurements of water-surface elevations by using a chalked, steel tape. Well elevations and channel-survey control points were surveyed to a common datum, and elevations are known to within $\pm 0.02 \mathrm{~m}$.

In order to isolate aquifer response measured in observation wells to increases in Mendenhall River stage, periods of record were examined during which groundwater recharge from precipitation was absent, and water-table elevations were stable or receding. In shallow, permeable groundwater systems like the Mendenhall Valley it can be difficult to distinguish if an aquifer is responding to river stage or precipitation recharge, because precipitation that elicits a rise in river stage also may elicit an increase in water-table elevation as precipitation infiltration rapidly recharges the aquifer. Due to its glacial source, the Mendenhall River is subject to rapid stage increases resulting exclusively from periods of increased glacial melt induced by warming temperatures; these periods of stage increases were selected for detailed analysis.

Daily precipitation and temperature data recorded at the Juneau airport were obtained from the National Weather Service (National Oceanic and Atmosphere Administration, 2004). The Juneau airport is near the mouth of the Mendenhall River, approximately $1.5 \mathrm{~km}$ south of the study area.

\section{Results}

\section{Channel Incision from 1969 to 1998}

Channel incision of the Mendenhall River from 1969 to 1998 was variable throughout the study reach (fig. 3). Minimum bed elevations decreased by as much as $4 \mathrm{~m}$ in 2 locations, not including a captured gravel-extraction pit, yet showed little change at some locations within the study reach. Some of these differences may be attributed to the finer resolution of the 1998 surveys, which included 24 additional cross sections that further defined channel geometry at pools and bends. Changes in mean bed elevation at the seven channel cross sections surveyed at replicated locations in 1969 and 1998 ranged from -0.4 to $-1.5 \mathrm{~m}$, and changes in minimum bed elevation ranged from -0.3 to -2.1 $\mathrm{m}$ (table 1). Similarities in changes in minimum and mean bed elevation suggest reductions in minimum bed elevation approximate changes in mean bed elevation throughout the study reach. The average decrease in both minimum and mean bed elevation for all cross sections was $1 \mathrm{~m}$. Assuming a constant rate of bed degradation; this decrease translates to a rate of $-0.03 \mathrm{~m} / \mathrm{y}$.

\section{Groundwater Level Observations}

\section{Well 29 from 1984-2001}

A linear declining trend in groundwater level was identified in data collected from 1984 through 2001 at observation well 29 (fig. 4). Because the water-level data exhibit large seasonal fluctuations, the Mann-Kendall seasonal test (Hirsch and others, 1982) was used to test for significance of the trend. This test is commonly used in hydrologic-data analysis (Helsel and Hirsch, 1992), and results indicated the trend in declining groundwater levels was statistically significant $(\alpha<0.05)$. The trend in declining groundwater levels in observation well 29 suggests a reduction in water table elevations of $0.6 \mathrm{~m}$ from 1984 to $2001(0.03 \mathrm{~m} / \mathrm{y})$. 
Table 1. Changes in minimum and mean bed elevations from 1969 to 1998 for seven cross sections surveyed on the Mendenhall River, Mendenhall Valley, southeastern Alaska.

\begin{tabular}{ccccccc}
\hline $\begin{array}{l}\text { Cross } \\
\text { section }\end{array}$ & $\begin{array}{c}\text { Minimum bed } \\
\text { elevation, in meters }\end{array}$ & $\begin{array}{c}\text { Change in } \\
\text { minimum bed } \\
\text { elevation, in } \\
\text { meters }\end{array}$ & $\begin{array}{c}\text { Mean bed elevation, } \\
\text { in meters }\end{array}$ & $\begin{array}{c}\text { Change in mean } \\
\text { bed elevation, in } \\
\text { meters }\end{array}$ \\
\hline 88 & 1969 & 1998 & & 1969 & 1998 & \\
\hline 80 & 9.6 & 8.9 & -0.7 & 10.2 & 9.5 & -0.7 \\
74 & 6.8 & 6.1 & -0.7 & 7.7 & 6.5 & -1.2 \\
59 & 6.0 & 4.1 & -2.0 & 6.6 & 5.5 & -1.1 \\
57 & 4.7 & 3.7 & -1.0 & 5.4 & 4.0 & -1.4 \\
52 & 4.0 & 3.5 & -0.5 & 4.8 & 4.0 & -0.8 \\
46 & 3.5 & 1.4 & -2.1 & 4.3 & 2.8 & -1.5 \\
\hline
\end{tabular}

\section{Wells 24 and 25 from 2001-2002}

No long-term monitoring of groundwater elevations has been conducted on the eastern side of the Mendenhall Valley, which prohibits empirical measurements of long-term watertable decline in wells 24 and 25 . However, linkages between river stage and water-table elevations were evident when well and Mendenhall River stage data were compared during four periods of increased glacial runoff during the study period. The rapid aquifer response to Mendenhall River stage increase during one of these periods is illustrated in figure 5. The recession of groundwater levels in the adjacent aquifer is halted following the glacial-melt induced stage increase. The rise in river stage is propagated rapidly into the aquifer, and

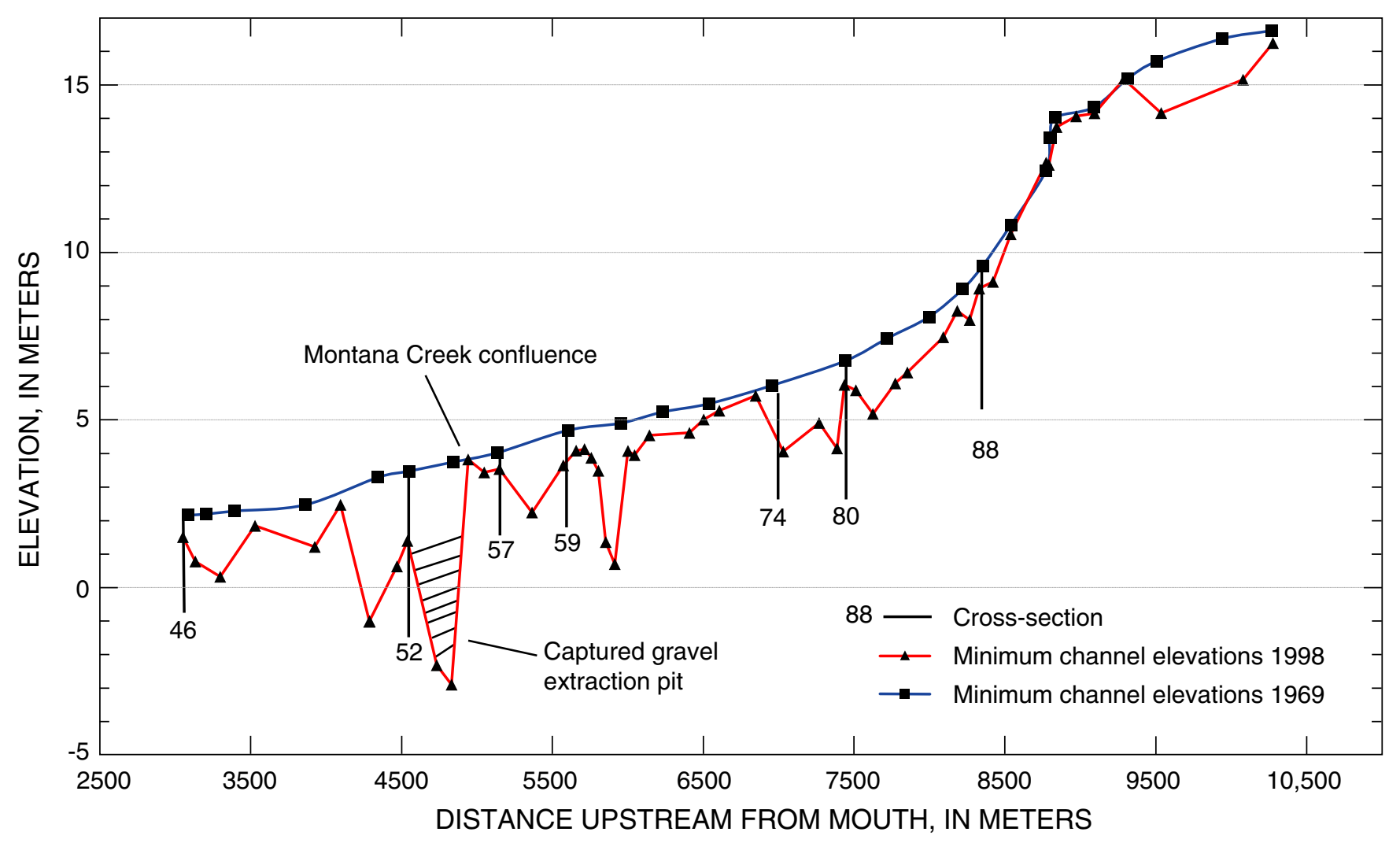

Figure 3. Longitudinal profile of Mendenhall River channel, southeastern Alaska, showing the minimum bed elevations and the locations of replicated cross sections surveyed in 1969 and 1998. 


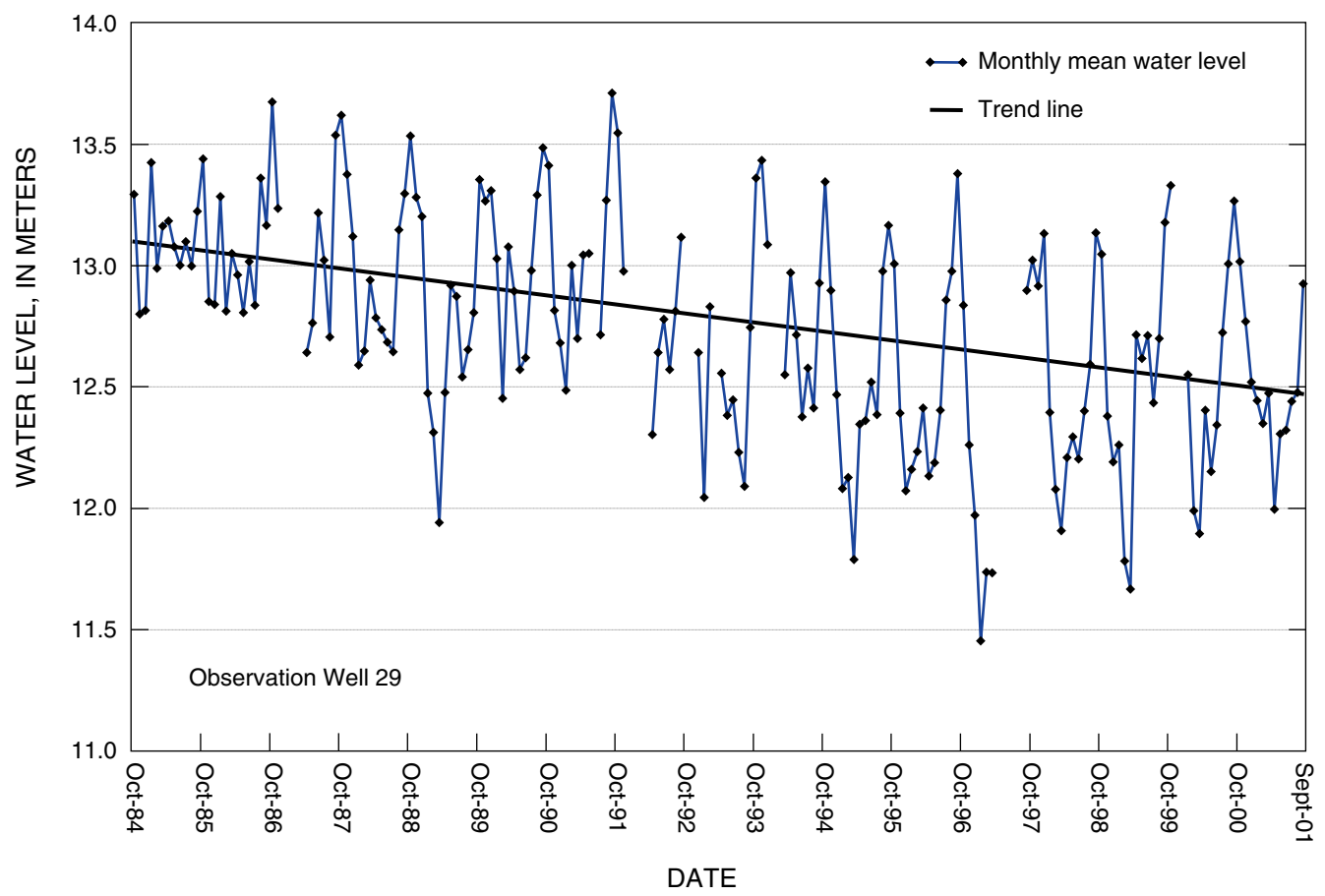

Figure 4. Monthly mean water levels recorded in observation well 29 from October 1984 through September 2001 illustrating the trend in declining water-table elevations, Mendenhall Valley, southeastern Alaska.

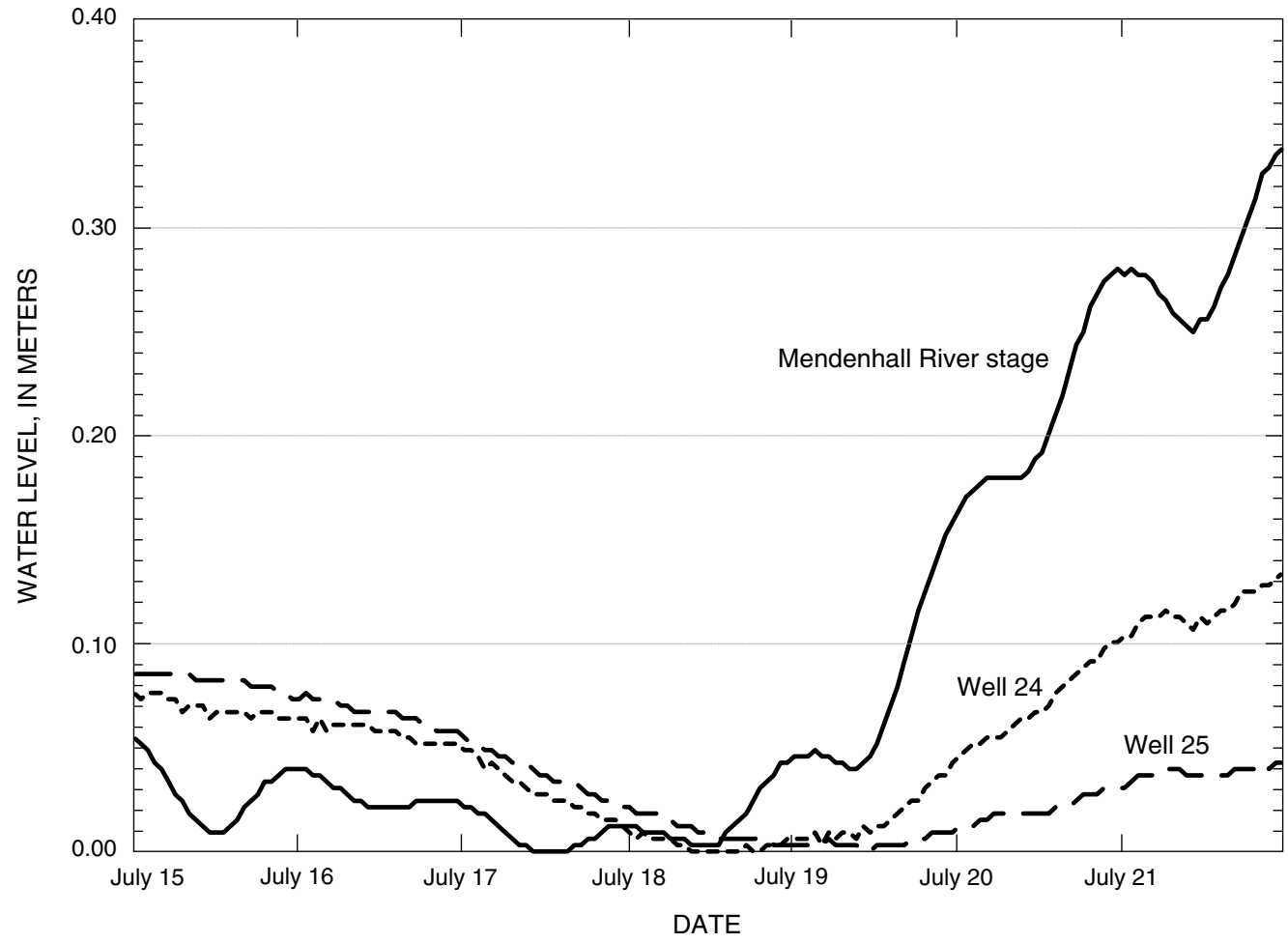

Figure 5. Plot showing changes in groundwater levels in observation wells 24 and 25 and Mendenhall River stage at the U.S. Geological Survey streamflow-gaging station from July 1521, 2001, Mendenhall Valley, southeastern Alaska. Data were recorded during a period with no groundwater recharge from precipitation. Mendenhall River stage increase was due to enhanced glacial melt induced by temperature increases from July 18-21. 
water-table elevation continues to rise throughout the warming event. The rise in water level in well 24 was about 40 percent of the rise in river stage, while the water-level rise in well 25 was about 15 percent of the rise in river stage. The total water-level response to stage increase may have been greater; however, the response is obscured by precipitation recharge the following day (July 22, 2001). Water levels were recorded in observation well 26 (fig. 1) during this event, and it demonstrated a response similar to that of well 25.

A similar groundwater-level-response analysis was performed during a period of precipitation recharge during the winter (fig. 6). In this instance Mendenhall River response to precipitation was minimal $(+0.1 \mathrm{~m})$ because precipitation fell as snow in the elevated and glaciated portion of the watershed, while the precipitation was predominantly rain in the lower elevations of the study area. The aquifer response to precipitation recharge is rapid, as infiltration proceeds quickly through the sand and gravel aquifer material.

Seasonal patterns in groundwater levels mirror the glacially driven runoff of the Mendenhall River hydrograph (fig. 7). The Mendenhall River typically rises during late spring and early summer as melting of the Mendenhall Glacier increases. Groundwater levels in wells 24 and 25 trace a similar, but slightly lagged increase, which attenuates with distance from the river. Both river stage and groundwater elevations decrease gradually throughout October and Novem- ber, concurrent with reductions in glacial melt, even though precipitation rates remain high in the study area. Water-table elevations are lowest during late winter and early spring as cool, dry weather reduces both glacial-melt contributions to streamflow and groundwater recharge from precipitation.

\section{Discussion}

\section{Channel Incision}

The retreat of the Mendenhall Glacier coinciding with the formation and enlargement of Mendenhall Lake since 1931 likely deprived the Mendenhall River of a supply of coarse sediment and initiated incision of the channel bed. Formation of proglacial lakes in the headwaters of river drainages has been shown to induce downstream-progressing channel incision, as decreased sediment loads result in flows with excess energy required to initiate channel degradation (Galay, 1983; Kondolf, 1997).

Evidence for Mendenhall River channel incision is not limited to repeat channel surveys. A series of aerial photos from 1948 through 2006 (fig. 8), indicate the channel configuration of the Mendenhall River has transitioned from a wider somewhat braided channel, more typical of a proglacial river

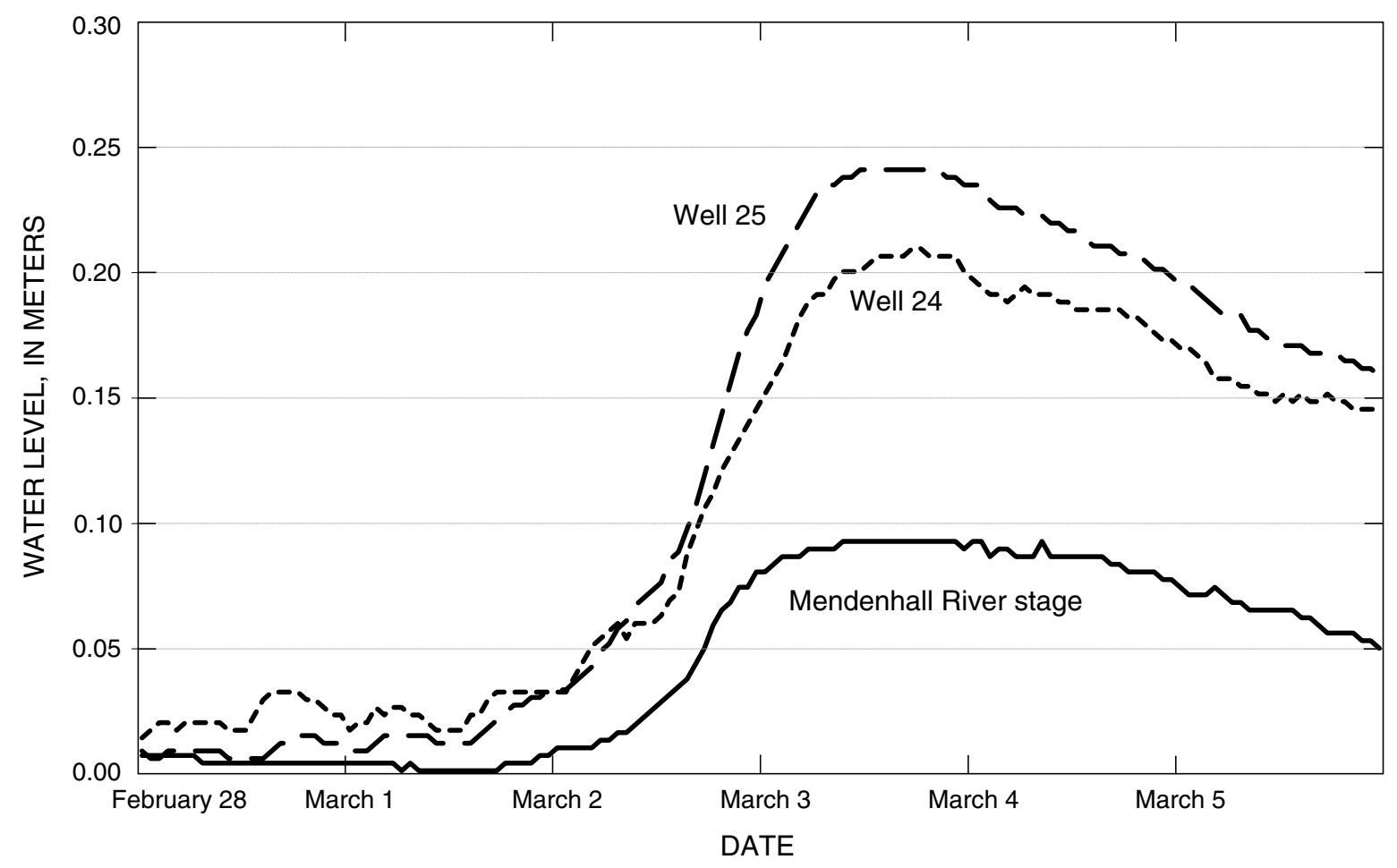

Figure 6. Precipitation recharge response in observation wells 24 and 25 and Mendenhall River stage measured from February 28 to March 5, 2002, Mendenhall Valley, southeastern Alaska. Precipitation totaled 22 mm on March 1 and 2, 2002. Warming associated with the precipitation melted an additional $12.7 \mathrm{~cm}$ of snow. 
with high rates of sediment transport, into a single-thread incising channel (compare Chew and Ashmore, 2001). Similar channel transitions have been observed following dam construction (Galay, 1983; Williams and Wolman, 1984; Kondolf and Swanson, 1993).

Aerial photos further revealed a gradual reduction in the number and size of gravel bars and the colonization of points, bars, and banks by immature spruce forest (fig. 8). A lack of flood plain definition provides additional evidence of an incising channel. The flood-profile model developed by Neal and Host (1999) showed that even 100-year flood flows will not overtop banks throughout the majority of the study reach, suggesting the top of the bank represents a terrace rather than a flood plain.
The variability in channel incision since 1969 (fig. 3) appears to be controlled primarily by the ability of channelbed material to resist erosion. For example, upstream from cross-section 88 , the river has carved a path through a sequence of moraines. Bed materials through this reach consist predominantly of large boulders with diameters exceeding 3 $\mathrm{m}$ (fig. 9). The finer materials have winnowed away, armoring the channel and limiting incision, resulting in bed elevations that have remained stable during the 29-year period between surveys. Localized grade control due to channel armoring has limited channel incision on other streams (Leopold and others, 1964, Galay, 1983, and Williams and Wolman, 1984). Incision also appears to have been limited by erosion-resistant peat deposits (which had been buried by subsequent outwash
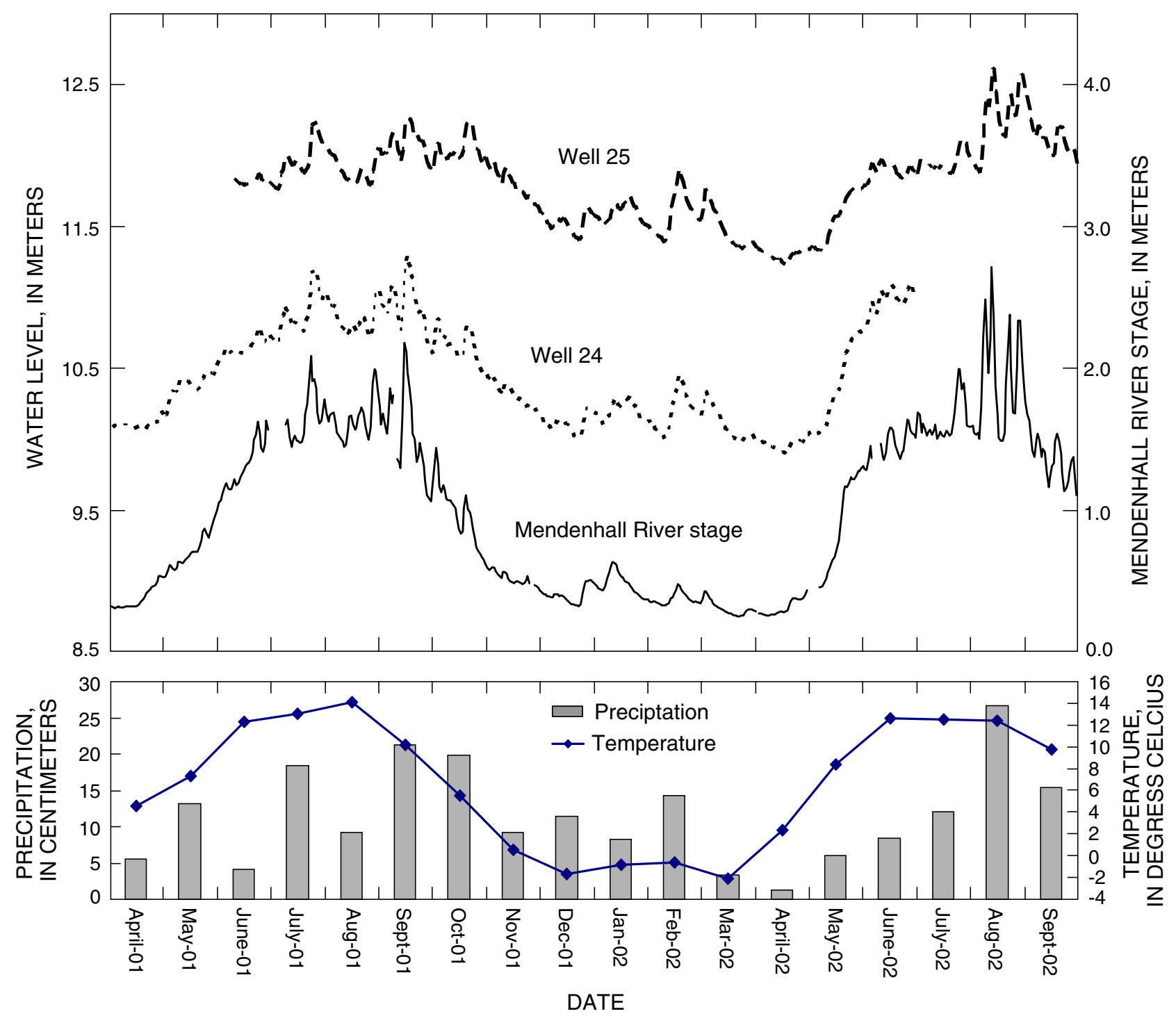

Figure 7. Water levels in observation wells 24 and 25, Mendenhall River stage, monthly precipitation totals, and mean monthly temperature from April 2001 through September 2002, Mendenhall Valley, southeastern Alaska. 
1948

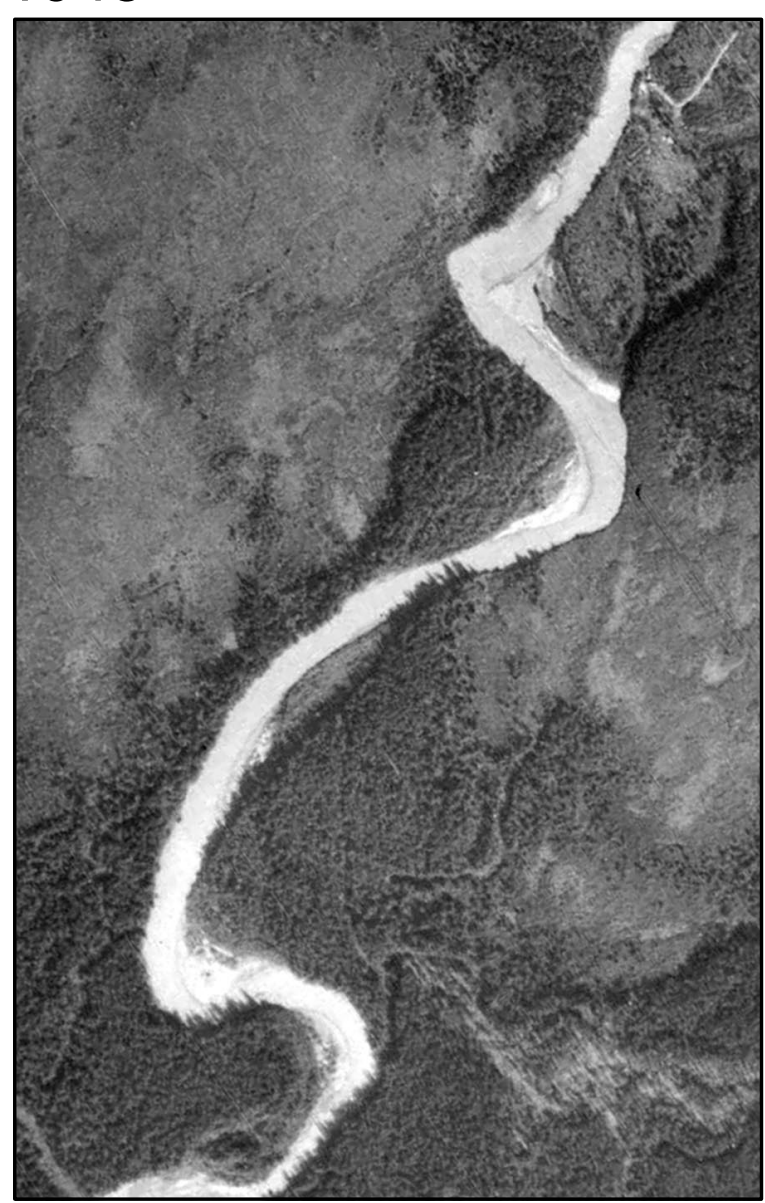

1962

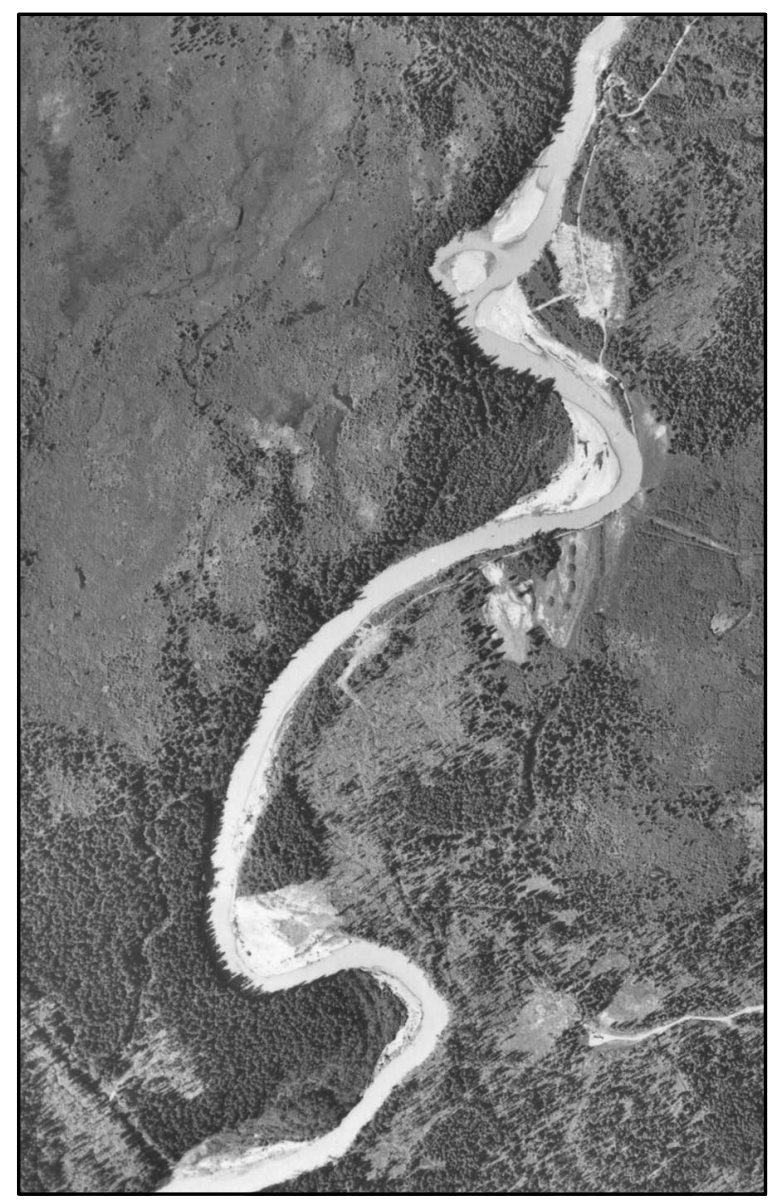

2005

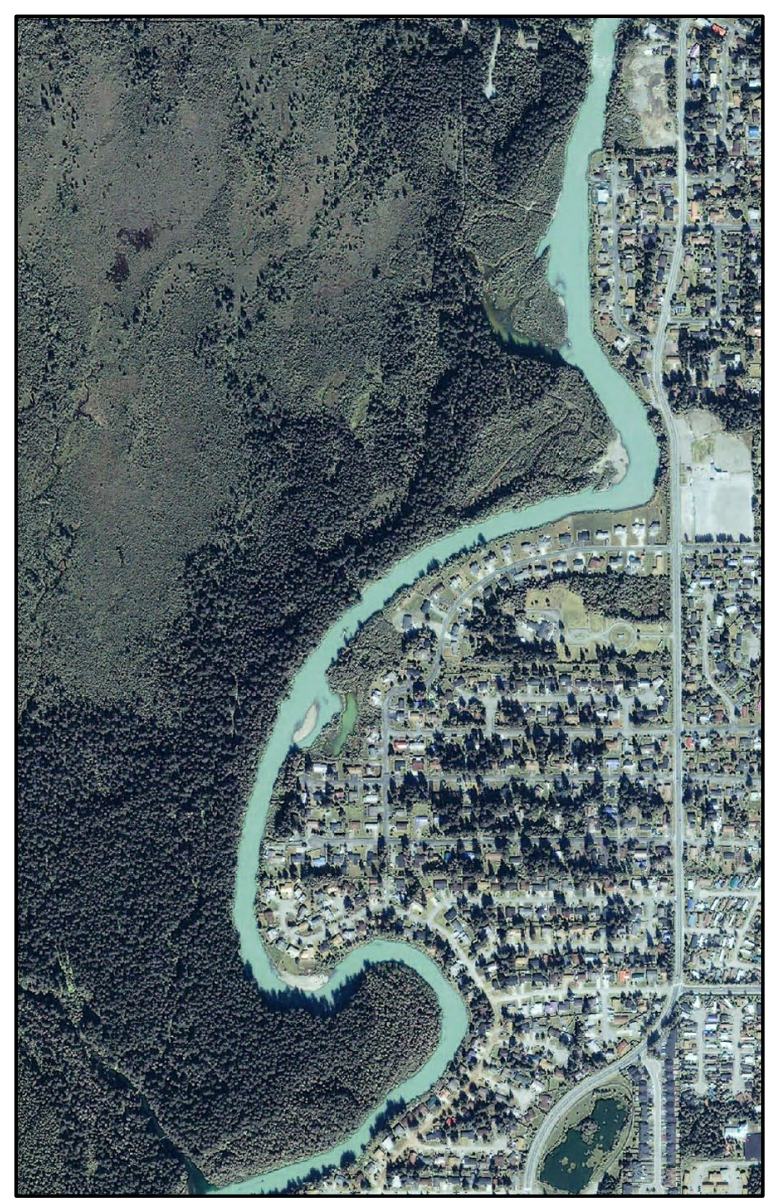

Figure 8. Aerial photos of the Mendenhall River channel, southeastern Alaska, from 1948 to 2005, showing a reduction in the number and size of gravel bars and colonization of points and bars by immature forest. 


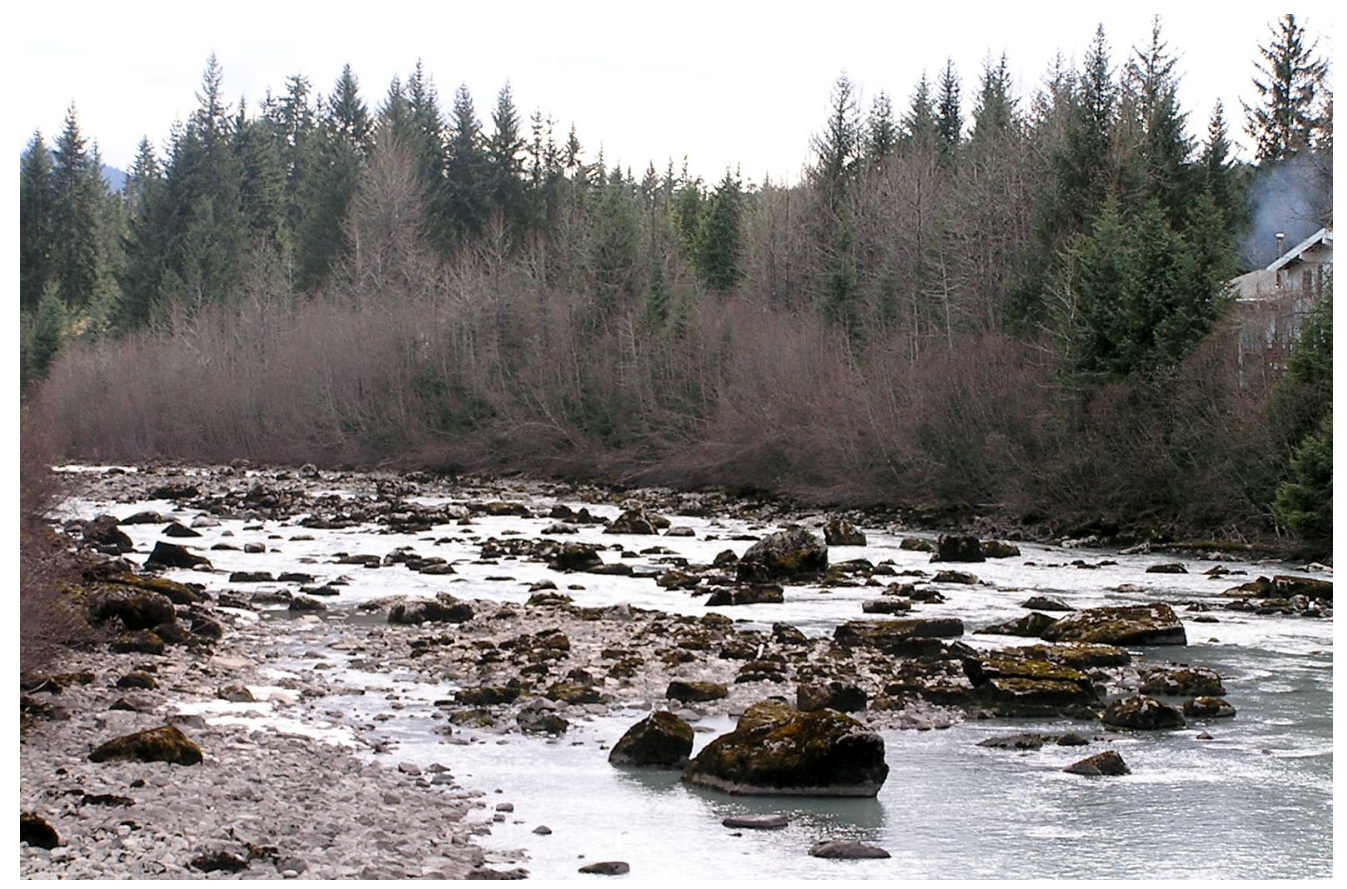

Figure 9. Photo of erosion resistant reach of the Mendenhall River, southeastern Alaska, showing the channel upstream of cross-section 88 , where the river has incised through moraine deposits leaving large cobbles and boulders armouring the channel.

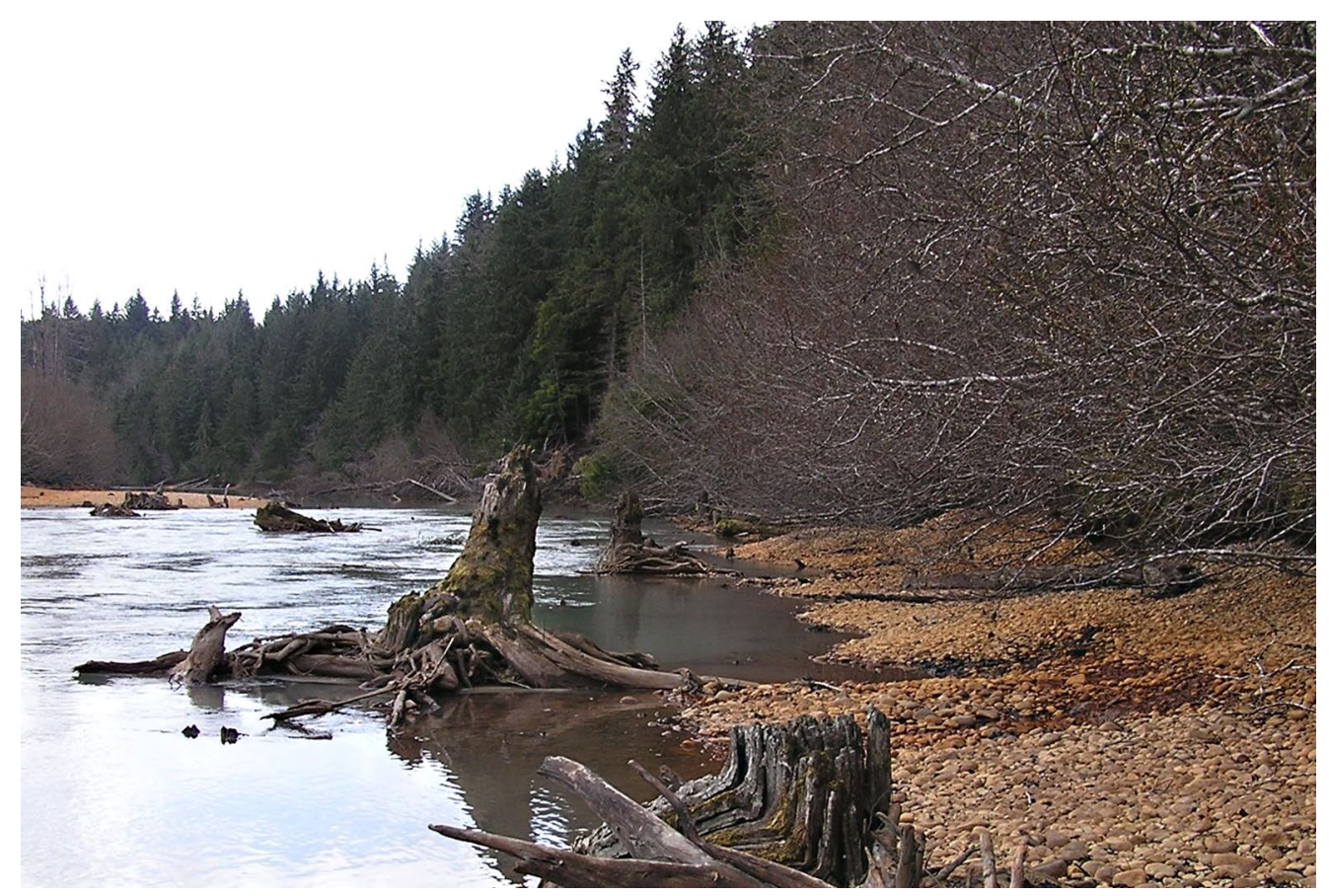

Figure 10. Photo of Mendenhall River, southeastern Alaska, showing a reach downstream of crosssection 74 , where the river has incised through outwash deposits exposing a peat layer overlain by a veneer of cobbles and upright stumps and root structures. 
deposits) between cross-sections 74 and 57 (figs. 1 and 3). Remnant root structures and trunks of trees remain upright and intact, lining the channel bed throughout a reach extending several hundred meters downstream from cross-section 74 (fig. 10). The peat deposits extend downstream to crosssection 57, although they are covered by a veneer of cobbles throughout much of the reach. Intermittent incision through the peat layers suggests they may eventually erode completely.

Detailed analysis of channel-incision processes in the Mendenhall River is complicated by the potential for both upstream-progressing channel incision, driven by declines in base level due to land-surface uplift, and downstreamprogressing channel incision driven by sediment trapping of Mendenhall Lake. Land-surface uplift rates in southeastern Alaska are among the greatest in the world and have been documented by global positioning system surveys (Larsen and others, 2004), tide-gage measurements (Hicks and Shofnos, 1965; Hudson and others, 1982; Savage and Plafker, 1991; Larsen and others, 2003), and studies of raised shorelines (Motyka, 2003). Although the region of maximum uplift is centered about $80 \mathrm{~km}$ to the northwest of the Mendenhall Valley, current uplift rates within the study area are estimated to be $1.3 \mathrm{~cm} / \mathrm{yr}$ (Larsen and others, 2003), with a total uplift of $3.1 \mathrm{~m}$ since 1800 (Motyka, 2003). Uplift of the Mendenhall Valley is the equivalent to a reduction in base level for the Mendenhall River. Reductions in base level have been shown to induce upstream-progressing channel incision in both flume experiments (Yoxall, 1969; Begin and others, 1981) and in natural fluvial systems (Galay, 1983; Hassan and Klein, 2002).

The ability to quantify historical rates or predict future rates of incision is complicated by the presence of erosion resistant bed material, channel armoring, and the potential for interference of incision processes in the Mendenhall River due to tributary-sediment sources. These complications do not, however, prohibit estimations of the magnitude of incision since the Mendenhall River abandoned its former channel on the eastern side of the Mendenhall Valley and established its current channel.

Estimates of incision from the time the river established its current channel are easily approximated due to the featureless, low-relief nature of the outwash plain through which the river has carved its current channel, such that the total amount of incision is approximated by the channel cross section. Assuming $1 \mathrm{~m}$ of channel incision observed between 1969 and 1998 represents a constant rate of bed degradation of 0.03 $\mathrm{m} / \mathrm{y}$, the total amount of incision since the formation of Mendenhall Lake would be a little more than $2 \mathrm{~m}$. These estimates should be considered conservative as incision rates typically decrease over time following the initiation of sediment trapping (Galay, 1983; Williams and Wolman, 1984). Modeled water-surface-profile elevations of 2-year flood discharges (Neal and Host, 1999) were compared to the elevation of the valley floor (top of bank) along the undeveloped west bank of the Mendenhall River. Results of the comparison show that the elevation of the valley floor remained perched 2.5 $\mathrm{m}$ above the modeled 2-year flood elevation throughout the reach extending downstream from cross section 80 to cross section 57.

\section{Water-Table Response to Channel Incision}

The trend in declining groundwater levels in well 29 (fig. 4) indicates a reduction in water-table elevations of $0.6 \mathrm{~m}$ from 1984 to $2001(0.03 \mathrm{~m} / \mathrm{y})$. The groundwater level decline does not appear to be related to long-term trends in streamflow or precipitation. Trends in precipitation have increased slightly when measured over a similar time period (Motyka and others, 2002). Mendenhall River exhibited no trends in decreasing discharge when examined over the same time period.

The rate of groundwater decline $(0.03 \mathrm{~m} / \mathrm{y})$ is remarkably similar to estimated rates of channel incision documented from 1969 to 1998 . Given the wells' proximity to the incised channel, coupled with the fact that surface water and groundwater are frequently connected in shallow aquifer systems; it appears that the decline in groundwater levels may be driven by channel incision. The hydrologic coupling of groundwater levels and Mendenhall River stage is further indicated by the rapid response of groundwater levels to stage increases during periods without groundwater recharge from precipitation (fig. $5)$.

Although water levels in wells 24 and 25 are shown to respond rapidly to precipitation recharge (fig. 6), the seasonal relationship between Mendenhall River stage and water levels suggests that water levels in the adjacent aquifer are controlled largely by the elevation of Mendenhall River stage (fig. 7). The Mendenhall River displays large seasonal variations in stage. These variations result primarily from increased glacial melt, increasing the stage by more than $1 \mathrm{~m}$ throughout the runoff season from mid-May to October. The seasonal change in stage is reflected in the water-table elevation of the adjacent outwash aquifer. The magnitude of influence stage exerts over the adjacent aquifer attenuates with distance from the river channel. This relationship between stage and groundwater level is shown also by the relative response to Mendenhall stage shown in figure 5 .

\section{Implications for Landscape and Adjacent Sur- face-Water Features}

The trend in declining water-table elevations identified in the long-term recording well coupled with measurements of channel incision, and the river-stage response exhibited in the three additional recording wells, suggests that channel incision is driving a reduction of water-table elevations in the Mendenhall Valley. Although it is beyond the scope of this investigation to generate historical water-table profiles in the Mendenhall Valley based on numerical models of aquifer characteristics and surface-water and groundwater interac- 
tions, figure 11 illustrates a likely sequence of transitioning hydrologic conditions.

When the Mendenhall River channel first breached the terminal moraine and formed its current channel, stage elevations would have been near or at land surface providing recharge to the adjacent aquifer year round and maintaining water-table elevations that were near or at land surface (fig.11A). Aerial photos from 1948 suggest that, prior to residential development on the east side of the Mendenhall River; the landscape in the vicinity of wells 24 and 25 was dominated by a mixture of forested wetlands and wetlands.
Wetlands adjacent to the west bank were identified as a fen (Siegel, 1988a). Fens are associated with groundwater discharge areas and suggest a water-table at or near land surface (Bedford, 2003). Following the formation of Mendenhall Lake and subsequent channel incision, water-table elevations declined as the stage of the Mendenhall River was reduced (figs. $11 B$ and $11 C$ ). The decline in river stage increased the hydraulic gradient across the valley floor, inducing water that was previously transmitted downvalley, within the shallow aquifer, to discharge into the Mendenhall River channel (compare Lach and Wyzga, 2002). Existing conditions are

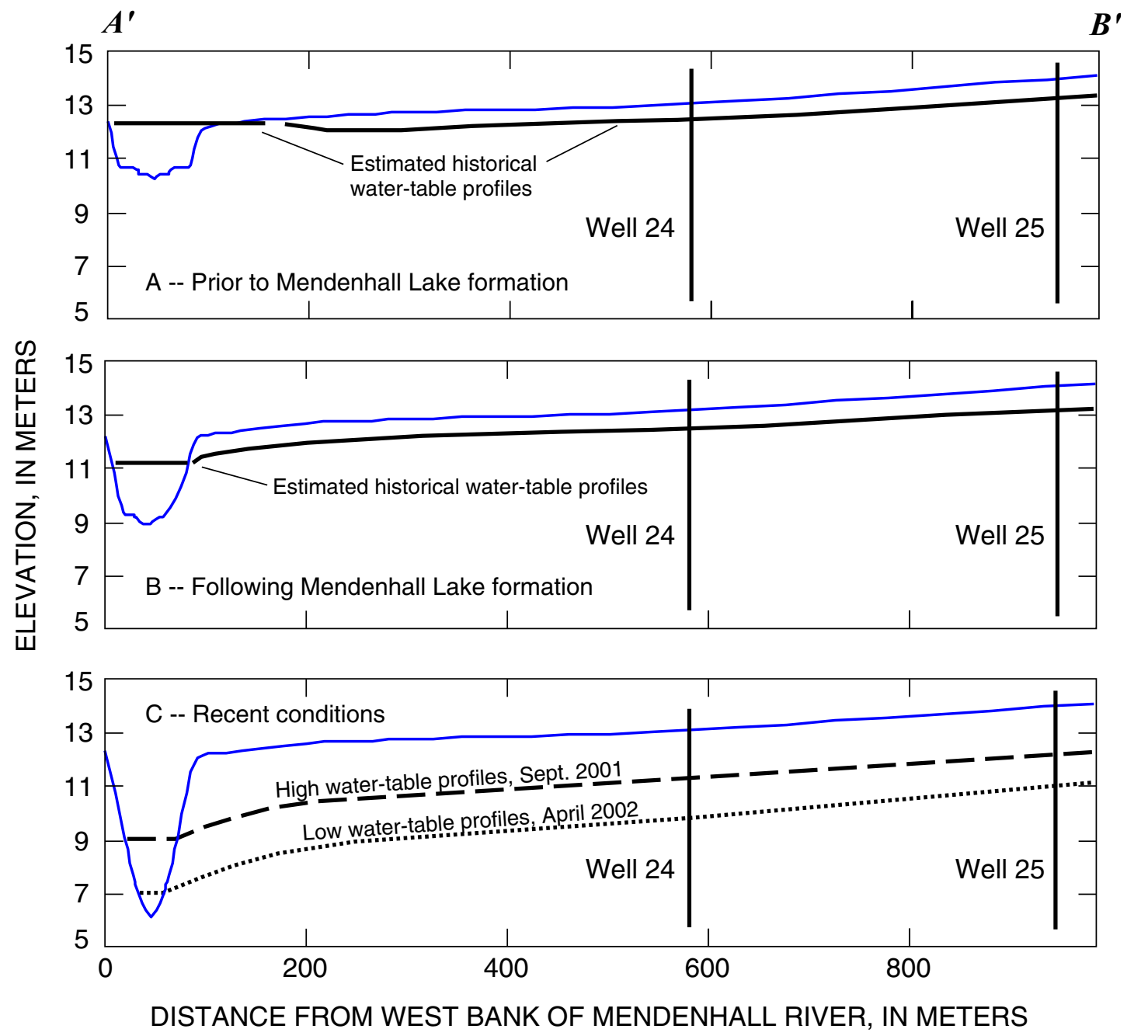

Figure 11. Cross sections showing inferred evolution of the Mendenhall River channel and adjacent watertable profiles over time at cross section $\mathrm{A}^{\prime}-\mathrm{B}^{\prime}$ (see fig. 1), southeastern Alaska. $A$, Inferred histrorical channel and water-table conditions, prior to the formation of Mendenhall Lake, when the river channel was shallow and wider, and river stage during the runoff season was near the elevation of the valley floor. Mendenhall River water provided recharge to the shallow aquifer. $B$, Inferred historical channel and water-table profiles following lake formation and channel incision, over-bank stages decreased in frequency, and adjacent water-table elevations were elevated with respect to present conditions. $C$, Recent conditions illustrating additional channel incision and water-table elevations derived from channel surveys, Mendenhall River stage data, and water levels measured in observation wells 24 and 25. Discharges with 2-year recurrence intervals remain more than $2 \mathrm{~m}$ below top of bank. 
such that the water- table elevations are now typically from 1.5 to $3.2 \mathrm{~m}$ below land surface.

The co evolution of channel planform, to a single-thread incised channel and the resulting reduction in water-table elevation of the Mendenhall Valley has important implications for adjacent surface-water features, such as off-channel wetlands and flood-plain side channels. For example, the fen wetlands adjacent to the west bank of the Mendenhall River across from wells 24 and 25 appear to be shrinking in response to a reduction in water-table elevations. Water-level measurements and analysis of chemical gradients identified the fen as a groundwater recharge zone (Siegel, 1988a,b), even though fens in North America typically are associated with groundwater discharge zones. The recharge function of the fen documented in Siegel's (1988a, b) investigation might be explained by declining water-table elevations. Channel incision followed by reductions in water-table elevation suggests that adjacent wetlands, which previously functioned as a groundwater discharge area, have been modified such that they now function as a groundwater recharge area. The composition of the vegetation found in 1988, which identified the wetland as a fen, was likely an artifact of a previously existing hydrogeologic setting. Comparisons of aerial photographs from 1948 and 2005 indicate rapid forest encroachment of more than 200 $\mathrm{m}$ into the previously existing fen (fig. 12). Field reconnais- sance of the area further indicates a shift in the composition of the vegetation to Sitka Spruce forest.

The reduction in water-table elevation associated with Mendenhall River channel incision also may be influencing discharges in an adjacent relic outwash channel known as Duck Creek. Duck Creek flows in a parallel course 500 to 1,000 $m$ east of the Mendenhall River (fig. 1). Baseflow in Duck Creek is maintained by groundwater discharge into the channel (McConaghy and Bowman, 1971). Once a perennial stream supporting four species of Pacific salmon (U.S. Environmental Protection Agency, 2000), Duck Creek now dewaters for several months during most years, and native salmon runs are extinct. Although reductions in Duck Creek discharges may have been influenced by residential development activities, such as road building, drainage diversions and land use, reductions in water-table elevation associated with channel incision may be contributing to baseflow reductions in this system.

\section{Conclusions}

The formation of Mendenhall Lake around 1931 resulted in reduced sediment supply to the Mendenhall River, likely initiating channel incision throughout the downstream reaches. Because the elevation of the water table at the study
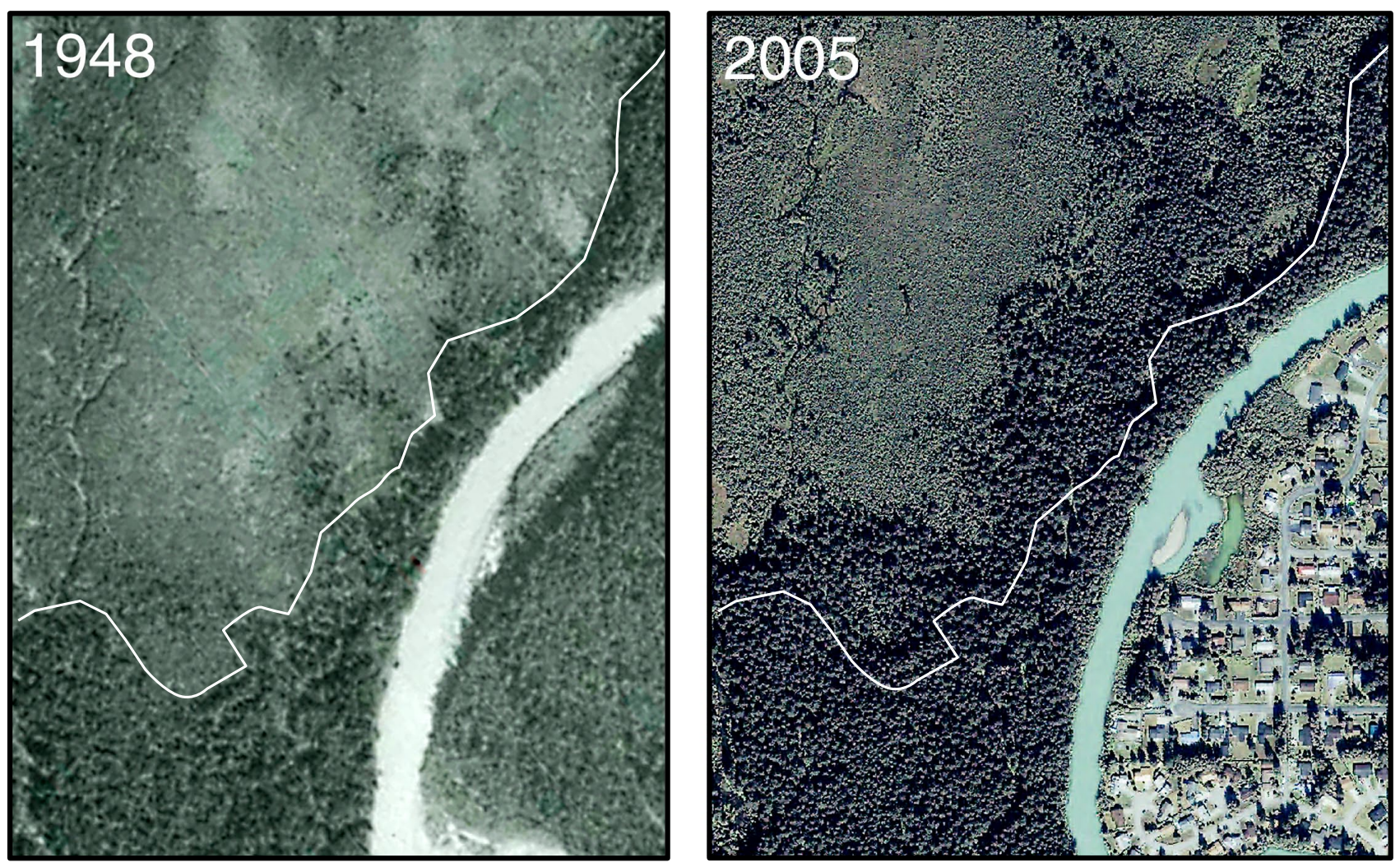

Figure 12. Aerial photos taken in 1948 and 2005 showing forest encroachment into the wetlands adjacent to the west bank of the Mendenhall River, southeastern Alaska. 
site is a function of both precipitation recharge and Mendenhall River stage, a trend in declining water-table elevation is attributed to incision of the river channel which has undergone reduced stage elevations throughout most of the study reach, inducing additional groundwater flow into the Mendenhall River channel.

The data from this study show the interactions between an alluvial outwash aquifer and the incised glacial stream to which it discharges. Results further demonstrate not only that seasonal patterns of river stage are propagated several hundred meters into the adjacent aquifer, but that relatively low levels of incision-induced river-stage reduction can affect groundwater levels to a degree capable of influencing adjacent surfacewater features, such as off-channel wetlands and flood-plain side channels. Numerous studies (Smith, 2005; Pollock and others, 2005; Kondolf, 1997) in California and the Pacific Northwest watersheds have speculated that small scale (1-2 m) channel incision, following wood removal or other channel modifications, has resulted in reduced groundwater elevations or storage, thereby causing a reduction in summer-time low flows and the dewatering of off-channel habitats and floodplain wetlands critical to juvenile salmonids. However, the intuitively sound hypotheses of the previous studies were not supported by empirical evidence.

Channel incision followed by subsequent lowering of the adjacent water table is likely to have wide-reaching implication in the maintenance and recovery of salmonid habitat throughout the Pacific Northwest. Findings presented here provide resource scientists and managers, evidence linking small-scale channel incision to reduced groundwater levels, as well as methods for developing long-term monitoring of the linkage between channel incision and groundwater levels.

\section{Acknowledgments}

This work was partly supported by the funding from the City and Borough of Juneau and the U.S. Forest Service. I would like to extend thanks to Roger K. Healy, Cynthia Lagoudakis, K Koski, and Steve Paustian for their support of this project.

\section{References Cited}

Bedford, B.L., 2003, Fens of the United States: Distribution, characteristics, and scientific connection versus legal isolation: Wetlands, v. 23, p. 608-629.

Begin, Z.B., Meyer D.F., and Schumm, S.A., 1981, Development of longitudinal profiles of alluvial channels in response to base level lowering: Earth Surface Processes Landforms, v. 6, p. 49-68.

Bigelow, B.B., Lamke, R.D., Still, P.J., Van Maanen, J.L., and Vaill, J.E., 1985, Water resources data, Alaska, water year
1984: U.S. Geological Survey Water-Data Report AK-8401, $350 \mathrm{p}$.

Bornette, G., and Heiler, G., 1994, Environmental and biological responses of former channels to river incision: a diachronic study on the upper Rhone River: Regulated Rivers: Research \& Management, v. 9, p.79-92.

Chew, L.C., and Ashmore, P.E., 2001, Channel adjustment and a test of rational regime theory in a proglacial braided stream: Geomorphology, v. 37, p. 43-63.

Coulter, H.W., and others, 1965, Map showing the extent of glaciation in Alaska: U.S. Geological Survey Miscellaneous Geologic Investigations Series Map I-415, scale $1: 2,500,000$.

Federal Emergency Management Agency, 1990, Flood insurance study, city and borough of Juneau, Alaska: Report revised, 1990, $42 \mathrm{p}$.

Galay, V.J., 1983, Causes of river bed degradation: Water Resources Research, v. 19, no. 5, p. 1057-1090.

Hassan, M.A., and Klein, M., 2002, Fluvial adjustment of the Lower Jordan River to a drop in the Dead Sea level: Geomorphology, v. 45, p. 21-33.

Helsel, D.R., and Hirsch, R.M., 1992, Statistical methods in water resources: Amsterdam, Elsevier Publishers, 529 p.

Hicks, S.D., and Shofnos, W., 1965, The determination of land emergence from sea level observations in Southeast Alaska: Journal of Geophysical Research, v. 70, no. 14, p. 33153320.

Hirsch, R.M., Slack, R.S., and Smith, R.A., 1982, Techniques of trend analysis for monthly water quality data: Water Resources Research, v. 18, no. 1, p. 107-121.

Hudson, T. K., Dixon, K., and Plafker, G., 1982, Regional uplift in southeastern Alaska, in Coonrad, W.L., (ed), The United States Geological Survey in AlaskaAccomplishments during 1980, U.S. Geological Survey Circular 844, p. 132-135.

Jacobson, R.B., 1995, Spatial controls on patterns of land-use induced stream disturbance at the drainage-basin scale-An example from gravel-bed streams of the Ozark Plateaus, Missouri, in Costa, J.E., Miller, A.J., Potter, K.W., and Wilcock, P.R. (eds), Natural and Anthropogenic Influences in Fluvial Geomorphology, American Geophysical Union, monograph 89, p. 219-239.

Jackson, M.L., Castor, M.E., Goetz, J.M., Solin, G.L., and Wiles, J.M., 2006, Water Resources Data, Alaska, Water Year 2005: U.S. Geological Survey Water-Data Report AK-05-1.

Kondolf, G.M., and Swanson, M.L., 1993, Channel adjustments to reservoir construction and instream gravel mining, Stony Creek, California: Environmental Geology and Water Science, v. 21, p. 256-269.

Kondolf, G.M., 1997, Hungry water: Effects of dams and gravel mining on river channels: Environmental Management v. 21, no. 4, p. 533-551.

Lach, J., Wyzga, B., 2002, Channel incision and flow increase of the upper Wisloka River, Southern Poland, subsequent to the reafforestation of its catchment: Earth Surface Processes 
and Landforms, v. 27, DOI: 10.1002/esp.329, p. 445-462.

Larsen, C.F., Echelmeyer, K.A., Freymueller, J.T., and Motyka, R.J., 2003, Tide gauge records of uplift along the northern Pacific-North American plate boundary, 1937 to 2001: Journal of Geophysical Research, v. 108, no. B4, p. $1-15$.

Larsen, C.F., Motyka, R.J., Freymueller, J.T., Echelmeyer, K.A., Ivins, E.R., 2004, Rapid uplift of southern Alaska caused by recent ice loss: Geophysical Journal International, v. 158 , no. 3 , p. 1118-1133.

Leopold, L.B., Wolman, M.G., Miller, J.P., 1964, Fluvial processes in geomorphology: San Francisco, W.H. Freeman, $522 \mathrm{p}$.

McConaghy, J.A., Bowman, W.N., 1971, Water resources of the City and Borough of Juneau, Alaska, U.S. Geological Survey Open-File Report 71-175, 62 p.

Miller, R.D., 1975, Surficial geologic map of the Juneau urban area and vicinity, Alaska: U.S. Geologic Survey Miscellaneous Investigation Series Map I-885, 1 sheet.

Motyka, R.J., 2003, Little Ice Age subsidence and post Little Ice Age uplift at Juneau, Alaska, inferred from dendrochronology and geomorphology: Quaternary Research, v. 59, p. 300-309.

Motyka, R.J., O’Neel, S., Conner, C.L., and Echelmeyer, K.A., 2002, Twentieth century thinning of Mendenhall Glacier, Alaska, and its relationship to climate, lake calving, and glacier run-off: Global and Planetary Change, v. 35, p. 93-112.

National Oceanic and Atmosphere Administration, 1984-2004, Local climatological data: U.S. Department of commerce, (published annually).

Neal, E.G., and Host, R.H., 1999, Hydrology, geomorphology, and flood profiles of the Mendenhall River, Juneau, Alaska: U.S. Geological Survey Water-Resources Investigations Report 99-4150, p. 35.

Pollock, M., Beechie, T., and Jordan, C., 2005, The effect of vegetation and beaver dams on geomorphic recovery rates of incised streams in the semi-arid regions of the Columbia River basin, USA [abs.]: Eos (American Geophysical Union
Transactions) Fall Meeting supp.

Savage, J.C., and Plafker, G., 1991, Tide gage measurements of uplift along the south coast of Alaska: Journal of Geophysical Research, v. 96, p. 4325-4335.

Scott, M.L., Lines, G.C., and Auble, G.T., 2000, Channel incision and patterns of cottonwood stress and mortality along the Mojave River, California: Journal of Arid Environments, v. 44, p. 399-414.

Schilling, E.E., Zhang, Y.K., and Drobney, P., 2004, Water table fluctuations near an incised stream, Walnut Creek, Iowa: Journal of Hydrology, v. 286, p. 236-248.

Shields, F.D., Knight, S.S., and Cooper, C.M., 1994, Effects of channel incision on base flow stream habitats and fishes: Environmental Management, v. 18, no. 1, p. 43-57.

Siegel, D.I., 1988, The recharge-discharge function of wetlands near Juneau, Alaska-Part I, hydrogeological investigations: Groundwater, v. 26, no. 4, p. 427-434.

Siegel, D.I., 1988, The recharge-discharge function of wetlands near Juneau, Alaska-Part II, geochemical investigations: Ground Water, v. 26, no. 5, p. 580-586.

Smith, C.J., 2005, Salmon habitat limiting factors in Washington State: Olympia, Washington State Conservation Commission.

U.S. Environmental Protection Agency, 2000, Total maximum daily load (TMDL) for fecal coliform bacteria in the waters of Duck Creek in the Mendenhall Valley [www.dec.state. ak.us/water/tmdl/pdfs/duckcreekfecaltmdl.pdf, last accessed November 25, 2006].

Williams, G.P., and Wolman, M.G., 1984, Downstream effects of dams on alluvial rivers: U.S. Geological Survey Professional Paper 1286.

Wurster, F.C., Cooper, D.J., and Sanford, W.E., 2003, Stream/aquifer interactions at Great Sand Dunes National Monument, Colorado-Influences on interdunal wetland disappearance: Journal of Hydrology, v. 271, p. 77-100.

Yoxall, W.H., 1969, The relationship between falling base level and lateral erosion in experimental streams: Geological Society of America Bulletin, v. 80, p. 13791384 . 
